\title{
References
}

1) Burstone, M. S. : Arch. Path., 63, 164-167, $1957 . \quad$ 2) Johnson, P. L., \& G. Bevelander, : Oral Surg. 10, 437-443, $1957 . \quad$ 3) Mori, M., W. Yoshioka, T. Mizushima, \& N. Amatsu, : Arch. hist. jap. 20, 513-522, $1960 . \quad$ 4) Yoshioka, W., M. Mori, T. Mizushima, \& T. Amatsu, : Arch. hist. jap. 20, 523-527, $1960 . \quad$ 5) Yoshioka, W., M. Mori, T. Mizushima, \& S. Deguchi, : Arch. hist. jap. 20, 529-533, 1960 6) Mori, M., W. Yoshioka, T. Mizushima, \& M. Murakami, : Arch. hist. jap. 20, 599-601, 1960.7 7) Quintarelli, G. : Arch. Ital. Biol. Orale, 2, 1-25, $1961 . \quad 8)$ Mizushima, T., M. Mori, W. Yoshioka, \& T. Tani, : Arch. hist. jap. 20,603-608, 1960. 9) Mori., T. Mizushima, \& K. Osanai, : Histochemie 2, 348-355, 1961. 10) Nachlas, M. M., D. G. Walker, \& A. M. Seligman, : J. Histochem. Cytochem. 4, 29-38, 1958. 11) Nachlas, M. M., D. G. Walker, \& A. M. Seligman, : J. Biophys, Biochem. Cytol. 4, 467-473, $1958 . \quad$ 12) Yamada, Y., T. Abe, \& N. Shimizu, : Arch. hist. jap. 23, 165-171, 1962. 13) Shiota, K. \& T. Shizuki, : J. Jap. Stom. Soc. (Abst) 10, 1961.

\section{Explanation of Figures}

Fig. 1: Succinic dehydrogenase. $\times 200$

Fig. 2: Latic dehydrogenase. $\times 200$

Fig. 3: Malic dehydrogenase. $\times 200$

Fig. 4: $\alpha$-Glycerophosphate dehydrogenase. $\times 100$

Fig. 5: $\beta$-Hydroxybutyric dehydrogenase. $\times 100$

Fig. 6: Aconitase. $\times 100$

\section{Histochemistry of Heterotopic Hard Tissue Formation}

\author{
Transplantation of Urinary Bladder Epithelium
}

\author{
Shusaku Yoshiki \\ Department of Pathology, Tokyo Dental College Tokyo, Japan
}

The present work deals with a histochemical analysis of the bone formation which is induced by implantation of the epithelium of urinary bladder. ${ }^{8-14,20)}$

The observations were primarily focused on the hyalinized tissue and what is called "abnormal bone tissue" "1) which appear during the bone induction, and some intrinsic difference in nature between the two tissues was indicated.

\section{Methods}

The animals used were guinea pigs which were from 3 to 5 months of age. They were divided into two groups, $A$ and $B$. In group $A$ the animals were anesthetized with a $1: 2: 3$ mixture of alcohol, chloroform and ether, their abdomen opened, small piece of the urinary bladder excised and autotransplanted into the abdominal subcutaneous tissue. ${ }^{14)}$ In group $\mathrm{B}, 10-20 \mathrm{mg}$. of aminoacetonitrile (AAN) was given to each animal by intramuscular injection every day from 5 days after the transplantation. ${ }^{14)}$ 
Three weeks after the operation, the implant was quickly excised with the surrounding tissue, and prepared into a serial fresh frozen sections of $15 \mu$ thick in a $-20^{\circ} \mathrm{C}$ cryostat. The sections were used for the demonstrations of alkaline phosphatase, ${ }^{19}$ ) acid phosphatase, ${ }^{3)}$ esterase, ${ }^{15)}$ aminopeptidase ${ }^{16)}$ and succinic dehydrogenase. ${ }^{17)}$ For the preliminary observations, additional sections were also examined under the hematoxylin eosin, van Gieson, von Kossa ${ }^{18)}$ and PAS stainings. ${ }^{18}$ )

\section{Results}

1. Hematoxylin-eosin, von Kossa, van Gieson and PAS staining.

In group $\mathrm{A}$ all cases showed a typical cyst formation due to an active proliferation of the implanted baldder epithelium. Beneath the epithelial lining of the cyst, a newly formed bone tissue was seen in the connective tissue. Fairly large amount of hyalinized tissue was also seen as a thin layer along the epithelial lining. It sohwed a rather homogeneous eosinophilic structure, containing a few cellular elements, stained red by van Gieson's method and was positive to PAS reaction.

In group $\mathrm{B}$, to which AAN had been administrated, the bone formation was seen to have been more active, and the bone was frequently noticed to be accompanied by a large amount of "abnormal bone tissue". No mineralization was determined in the "abnormal bone tissue" by von Kossa staining and the staining reactions to hematoxylin-eosin, van Gieson and PAS of this tissue were essentially the same with those of the hyalinized tissue seen in group A.

\section{Enzyme activities}

The present results concerning the activities of various enzymes in the bone induced by the urinary bladder epithelium were in agreement with many earlier works carried out with normally developing bone. ${ }^{1,2,4-7,21)}$ The mineralized bone matrix showed no activities of alkaline phosphatase, aminopeptidase and succinic dehydrogenase, while rather strong activities of acid phosphatase and esterase were confirmed in it.

One of the interesting features of the present study was the difference in the enzyme activities between the hyalinized tissue and the "abnormal bone tissue". As was explained before, there was no difference in the staining reactions to hematoxylin eosin, van Gieson and PAS, between these two tissues. Enzyme histochemically, however, a remarkable difference between the two was confirmed. While the hyalinized tissue did not show any enzyme activity, a strong activity of alkaline phosphatase was always determined in the "abnormal bone tissue". Moderate or weak activities of acid phosphatase and esterase were also detected in it.

\section{Discussion}

In his recent report Kobayashi ${ }^{14)}$ has assumed that the hyalinized tissue is possibly brought about as a result of some modification of the connective tissue and that what is called the "abnormal bone tissue" may be attributed to a 


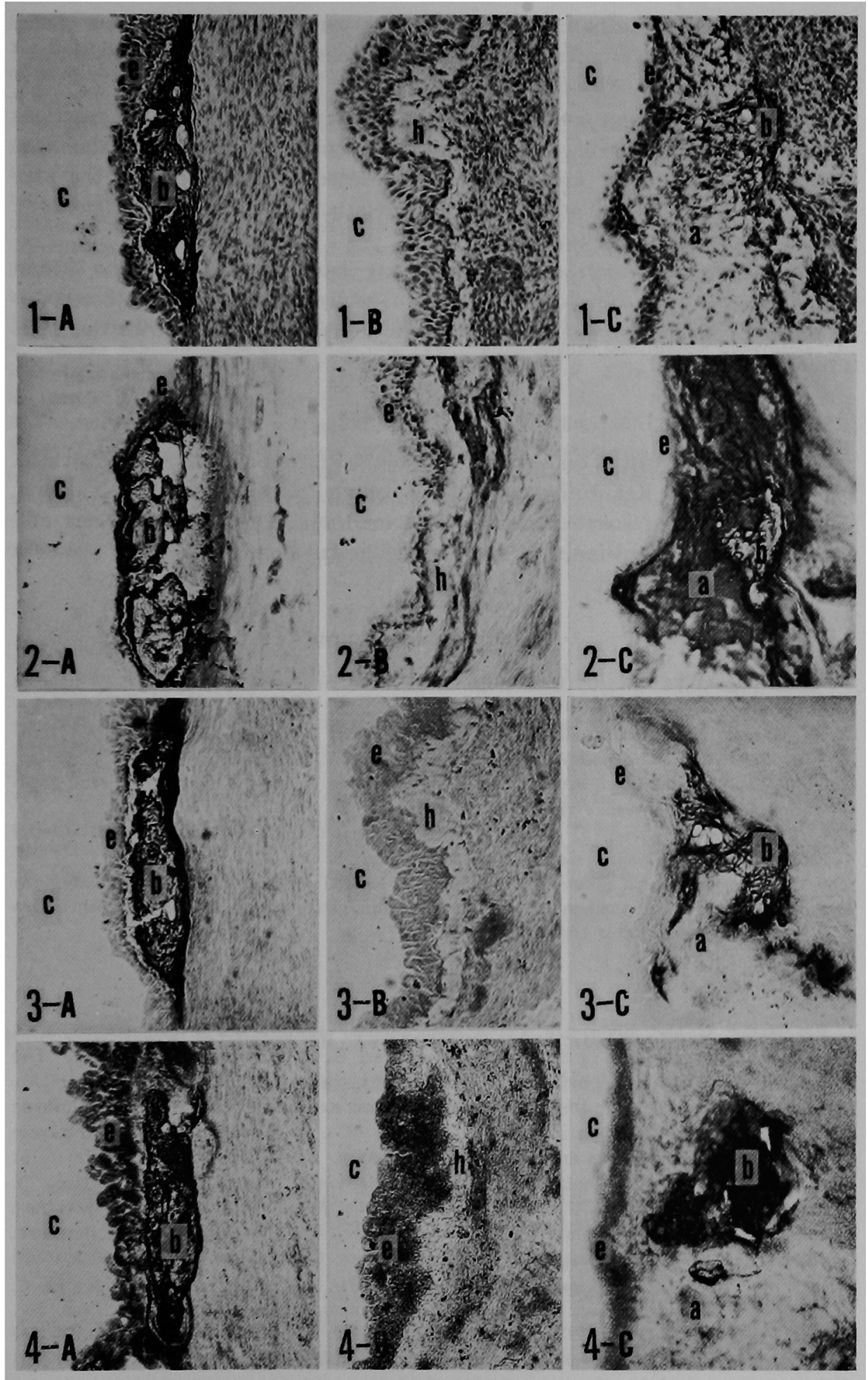


transitional or intermediate type between the bone and the hyalinized tissue. No intrinsic difference, however, has so far been observed between the hyalinized and the abnormal bone tissues.

Through the present study, a remarkable difference in the enzyme reactions was determined between the two tissues. The enzyme reactions in the "abnormal bone tissue" is basically same with those observed by the author in the premineralized matrix which appears in a close relationship with the experimentally formed heterotopic hard tissue. ${ }^{22}$

The "abnormal bone tissue" would be attributed, therefore, to the osteoid tissue which is ready to be mineralized. The hyalinized tissue is thought to be a mere collagenous matrix and to have no direct relation with the bone formation.

\section{Acknowledgement}

The author expresses his sincere gratitude to Professor Tadayoshi Kobayashi, Dept. of Pathology, Keio University, and Assistant Professor Shosaburo Takuma, Dept. of Pathology, Tokyo Dental College for their valuable suggestions and advices. Also, the assistance of Mr. Tadashi Okuyama in the experiments is gratefully acknowledged.

\section{Explanation of Figures}

Bone (Figs. A), hyalinized tissue (Figs. B) and "abnormal bone tissue" (Figs. C) induced by transplantion of the urinary bladder epithelium. $\times 65$.

Figs. 1. Hematoxylin-eosin, Figs. 2. Alkaline phosphatase,

Figs. 3. Acid phosphatase, Figs. 4. Esterase.

A:- The bone (b) is shown beneath the epithelial lining (e) of the cyst (c). Serial fresh frozen sections, 3 weeks after transplantation.

B:- The hyalinized tissue (h) runs along the epithelial lining (e) of the cyst (c). Serial fresh frozen sections, 3 weeks after transplantation.

C:- The "abnormal bone tissue" (a) is seen to be located between the epithelial lining (e) of the cyst (c) and the bone (b) in the AAN-administrated animal. Serial fresh frozen sections, 3 weeks after transplantation.

\section{References}

1) Bevelander, G. and Johnson, P. L. : A histochemical study of the development of membrane bone. Anat. Rec. $108: 1-21,1950$. 2) Bourne, G. H. : Phosphatase and bone. The biochemistry and physiology of bone (Ed. by G. H. Bourne). Academic Press, N. Y. p.251286, 1956. 3) Burton, J. F. : Histochemical demonstration of acid phosphatase by an improved azo dye method. J. Histochem. Cytochem. 2: 88-94, $1954 . \quad$ 4) Burstone, M. S. : Esterase activity of developing bones and teeth. A. M. A. Arch. Pathol. 63:164-167, $1957 . \quad 5$ ) Burstone, M. S. : Acid phosphatase activity of calcifying bone and dentin matrices. J. Histochem. Cytochem. $7: 147-148,1959 . \quad 6)$ Burstone, M. S. : Histochemical observations on enzymatic processes and teeth. Ann. N. Y. Acad. Sci. $85: 431-444,1960.7$ 7) Burstone, Hydrolytic enzymes in dentinogenesis and osteogenesis. Calcification in biological systems (Ed. by R. F. Sognnaes). Amer. Ass. Advance Sci. 64:217-243, $1960 . \quad$ 8) Huggins, C. B. : Influence of urinary tract mucosa on the experimental formation of bone. Proc. Soc. exp. Biol. Med. $27: 349-351,1930.9$ 9) Huggins, C. B. : The formation of bone under the influence of epithelium of the urinary tract. Arch. Surg. $22: 377-408,1931.10$ ) Huggios, C. B. and Sammet, J. F. : Function of the gall bladder epithelium as an osteogenic stimulus 
and the physiological differentiation of connective tissue. J. exp. Med. $58: 393-400,1933$. 11) Huggins, C. B., McCarroll, H. R. and Blocksom B. H. Jr. : Experiments on the theory of osteogenesis. The influence of local calcium deposits on ossification; the osteogenic stimulus of epithelium. Arch. Surg. $32: 915-931,1936 . \quad 12)$ Huggins, C. B. : The phosphatase activity of transplants of the epithelium of the urinary bladder to the abdominal wall producing heterotopic ossification. Biochem. J. $25: 728-732,1938$. 13) Kobayashi, T., Izumi, K. and Miyairi, B. : Experimental bone formation induced by urinary bladder epithelium. Trans. Soc. Pathol. Jap. $41: 311-312,1952$. 14) Kobayashi, T.: The problems on tissue induction in the pathological field. Trans. Soc. Pathol. Jap. 50:91-120, 1961 . 15) Nachlas, M. M.: The histochemical demonstration of esierase. J. nat. Cancer Inst. $9: 415-425,1949.116$ ) Nachals, M. M., Crawford, D. T. and Seligman, A. M. : The histochemical demonstration of leucine aminopeptidase. J. Histochem. Cytochem. $5: 264-278,1957$. 17) Nachlas, M. M., Tsou, K. C., Souza, E. D., Cheng, C. S. and Seligman, A. M. : Cytochemical demonstration of succinic dehydrogenase by the use of a new p-nitro-phenyl substituted ditetrazole. J. Histochem. Cytochem. $5: 420-436,1957 . \quad 18)$ Okamoto, K., Ueda, M. and Maeda, R. : Microscopic histochemistry. (1st Ed.), Igaku Shoin, Tokyo, 1955.19 ) Pearse, S. G. E. : Histochemistry. Theoretical and applied. (2nd Ed.) p.872, Churchill, London, 1960.2 20) Yasui, Y. : Studies on the influences to the induction of mesenchymal tissues by epithelial cells. J. Keio med. Soc. $35: 961-969,1958 . \quad 21)$ Yoshiki, S. : Histochemistry of various enzymes in developing bone, cartilage and tooth of rat. Bull. Tokyo dent. Coll. $3: 14-28$, 1962. 22) Yoshiki, S. : Histological and histochemical study on experimental heterotopic hard tissue formation. Trans. Soc. Pathol. Jap. 51 : (in press), 1962.

\title{
Discussion
}

Dr. Chin

When intra-ocular inflammation continues for long period of time, it is not rare to recog. nize intra-ocular ossification.

How do you think about the mechanisms of inducing osseous tissues with the transplantation of urinary bladder epithelium ?

Dr. Yoshiki

Though various factors are considered to be responsible for inducing osseous tissues with the transplantation of epithelial tissues, I have not enough data to give satisfactory answers to your question. In this study I haoe intended to compare the histochemical findings of normal osseous tissues with those of induced osseous tissues.

\section{Histochemical Studies on Transition of Phosphatase Activities in the Processes of Bone Repair}

\author{
Kazuaki TAKADA \\ Department of Oral Surgery, Osaka University Dental School, Osaka, Japan \\ Director. Prof. Dr. Kensaku Kawakatsu
}

On the bone repair many investigations have been done with histological, physical and chemical techniques, however, there is a few report about histochemical demonstration, especially, as to the acid phosphatase activity in repairing process of bone. 